\title{
Traditions, continuity and new approaches in the formation of modern Russian entrepreneurship
}

\author{
N.A. Dushkova ${ }^{1,{ }^{*}}, A . V$. Perepelitsyn $^{2}$, and V.A.Grigorova ${ }^{3}$ \\ ${ }^{1}$ Voronezh State Technical University, Voronezh, Russia \\ ${ }^{2}$ Voronezh State Pedagogical University, Voronezh, Russia \\ ${ }^{3}$ Voronezh Institute of the Ministry of Internal Affairs of the Russian Federation, Voronezh, Russia
}

\begin{abstract}
The article reveals the importance of entrepreneurship, which is undergoing a revival stage, for the successful development of Russian society. In this regard, the author analyzes the question of what positive qualities of their predecessors could be borrowed by modern entrepreneurs. Without hushing up the negative characteristics of the manufacturers and breeders of the 19th - early 20th centuries, the authors focused on their business abilities, on their activity, primarily in production activities, on the ability to combine personal interests with national interests, on charity and patronage. The article emphasizes that it is important for a successful entrepreneur not only to continue the best traditions of Russian business, but also to notice new, advanced phenomena in the economy and society, be able to master them, achieve more in life, strive not only for personal wealth, but also take care of prosperity of the homeland.
\end{abstract}

\section{Introduction}

Since the end of the twentieth century, in Russia, along with the transition to a market economy, there has been a process of revival of the entrepreneurial stratum. Over the years, its representatives managed to become a certain part of society, to become part of the economic and political elite of the state. At the same time, they had to overcome many internal obstacles, experience the difficulties of the world economic crisis together with the whole country, and withstand the shock of anti-Russian sanctions. New obstacles have emerged in the wake of the COVID-19 pandemic: decrease in economy, cutbacks in production, shutdown of enterprises, falling oil prices, bankruptcy of private companies, etc.

And nevertheless, the way out of the current situation, the recovery of the economy by the country's leadership, is seen through the revival, first of all, of business, which has become one of the main driving forces of the new socio-economic system in Russia.

However, business is charged with the task of not only overcoming the consequences of the coronavirus and stabilizing the situation, but also ensuring the country's further progress. Russia can and should take its rightful place in the world economy. And much

\footnotetext{
* Corresponding author: dushkova12@mail.ru
} 
will depend on the ability of domestic entrepreneurs to achieve an increase in production efficiency, be competitive, and act as a stabilizing factor in development.

In order to cope with all the tasks, entrepreneurs must have certain qualities, abilities, take into account the traditions of domestic business, the originality of the Russian way of life, and mentality. In this regard, it makes sense to refer to the historical experience of the entrepreneurial stratum in pre-revolutionary Russia, to identify its strengths and weaknesses, to reveal significant traditions for possible continuity in modern business. It is also important to consider new phenomena in the entrepreneurial sphere that have appeared in the context of the revival of market relations and which require attention and further development.

\section{Materials and methods}

The article used the principle of historicism, as well as such general scientific methods as analysis and synthesis, induction and deduction. They made it possible to reveal the qualitative characteristics of entrepreneurs in pre-revolutionary Russia that could be perceived by domestic business at the present time, made it possible to identify new phenomena in the formation of modern entrepreneurship, to justify the increase in its role and importance in solving the problems of sustainable economic growth.

\section{Results and Discussion}

The growing role of the entrepreneurial stratum in Russian society has led to an increased interest of scientists in this issue. Economists, historians, sociologists, political scientists are engaged in its development. But the most generalized study of Russian entrepreneurship from its origins to the beginning of the twentieth century is "History of Entrepreneurship in Russia" team work in 2 books edited by A.V. Semenov [1].

It should be noted that historians prefer to deal mainly with the study of prerevolutionary entrepreneurship, leaving economists, political scientists, sociologists with the problems of the current stage of its development. But progress in this direction is slow and not many works are published. We can only mention the works of S. Vorobyov [2], A. Logunov [3], Nikiforov [4].

On the contrary, Western researchers are more interested in modern entrepreneurship. And American authors set the style here. Analyzing various aspects of business, they try to look into the future, to determine, to some extent, a development perspective. Among them are the so-called modern classics of entrepreneurship theory, who received awards for their contribution to the development of this topic. These include, first of all, D. Burch, who is considered a pioneer in the study of small business [5]. Various aspects of small and medium-sized businesses are considered in their works by authors such as W. Gartner [6], S. Shane [7], G. Aldrich [8].

Coinciding with his compatriots about the importance of small and medium-sized businesses, W. Baumol [9] nevertheless notes that he can only accumulate breakthrough ideas. And the last word still belongs to large companies, which ensure the speed of the spread of these ideas and the scale of their implementation. And ideally, they should definitely cooperate with each other.

With the undoubted results obtained in the course of scientific research on entrepreneurship, there are still a lot of problems that need to be studied both at the theoretical and empirical levels.

This article will discuss one of them. It is important to analyze to what extent it is possible in Russia to use the past experience of entrepreneurship, how to ensure the 
continuity of the best traditions, how to combine the past with new phenomena, to form not just a business, but a socially responsible business that ensures sustainable economic growth and stability in society.

In Russia, there have always been a lot of business people who have a clear mind, a good knowledge of economic conditions, capable of looking for new economic solutions. The strongest impetus for the activation of domestic entrepreneurship was the bourgeois reforms from the middle of the 19th century. The composition of the emerging industrial bourgeoisie was represented by the merchants, the bourgeoisie, but mainly by the rich peasantry. It is from the latter that whole dynasties of Russian manufacturers will be created: the Ryabushinskys, Guchkovs, Morozovs Yamanovskys, Prokhorovs, Gandurins, Alekseevs, etc.

The nobles were also involved in business activities. Princes Dolgoruky, Buryatinsky, Yusupovs, Counts Pototsky, Orlovs owned sugar factories, Counts Shuvalovs, Stroganovs owned metalworking factories.

The entrepreneurs were able to fully demonstrate their business qualities and make a huge contribution to the creation of domestic industry, to the development of new sectors of the economy. By the beginning of the twentieth century, more than 400 thousand industrial enterprises of various sizes worked in Russia. During the years of economic growth - 19091913 , - heavy industry increased its production by $85 \%$, light industry - by $40 \%$. In terms of industrial production as a whole, Russia ranked 5th in the world, and in terms of the production of mechanical engineering - had the 4th place [10].

At the same time, the entrepreneurs did not initially demonstrate the best human qualities for the sake of obtaining the super-profits. They were characterized by greed, a tendency to deceive, speculation, an impetuous passion for profit.

Over time, the social image of the Russian bourgeoisie will change. The technical excellence of production, the desire for education, and the expansion of the range of motivation for entrepreneurial activity will have an impact. An understanding will come about the need to introduce the civilized approaches to the workforce. At the end of the XIX century, a typical representative of the Russian bourgeoisie will be characterized by patriotism, hostility to Western liberal ideas, interest in raising the social status, restraint in the means of enrichment [11].

They will also become characterized by a strong craving for education, for cultural values. They became famous collectors of book rarities, passionate bibliophiles, inveterate theatergoers. Compatriots and foreigners were amazed at the boundless generosity of the manufacturers. And at the same time, being under the influence of the Christian faith and especially the Old Believers, they tried to justify themselves, as it were, for the acquired wealth, luxury, for a riotous lifestyle, for a high social status. At the same time, mercantile goals were not alien to them. Through charity, patronage, one could prove one's material viability, earn public recognition, receive orders, titles, and the long-awaited nobility.

As the education of manufacturers and breeders grows, the nature of their relationship with workers changes. Gradually, some of them began to abandon cruel forms of exploitation and moved on to measures to improve the working and living conditions of their workers. These entrepreneurs include: the Ryabushinsky brothers, S.I. Chetverikov, S.T. Morozov, etc. Public opinion also changed towards them. They gained reverence and respect.

And yet there were not many such examples. The business world was dominated by other representatives of the bourgeoisie: predatory, greedy, indifferent to ordinary people. This prevented the establishment of an acceptable relationship between labor and capital, which ultimately culminated in a revolutionary explosion. 
At present, when, after a long break, the transition to a market economy has again occurred in Russia, an entrepreneurial stratum has begun to form. Its ranks, as before, are joined by people with initiative, business activity, perseverance, determination, etc.

But there is also a fundamental difference. In the past, whether entrepreneurs were inherently successful or not very successful, noble or greedy, most of them were included in production activities. They built factories and plants, were engaged in the construction of roads and houses, tried to expand their production and technically improve it. In this way, they increased their material condition, while strengthening the economic position of the state. Their social image was shaped by the environment. Russian entrepreneurs received moral principles that were passed on to them through generations, as well as absorbed wellestablished traditions and customs. And therefore, their economic activity, as a rule, was aimed not only at gaining personal benefit, but also correlated with public benefit, was associated with a sense of duty and personal responsibility for the fate of the Fatherland.

At the present time, when entrepreneurship in Russia is still in its infancy, many of its representatives are passionate about commercial activities, not production. And this leads to enrichment primarily of the owner, not the state.

In addition, in Russia, as in the whole world, changes are taking place in the very structure of the business. Gigantomania is being replaced by small and medium-sized businesses (SMB), which have clear advantages. It is characterized by such features as extraordinary flexibility, adaptability. It serves as the main source of innovation, a generator of new solutions, and successfully solves the problem of employment.

However, so far the efficiency of domestic SMB is low. Its contribution to the Russian economy is about $25 \%$, while this figure is $50-60 \%$ in the advanced countries of the world [12]. This is explained by the fact that SMB are penetrating the mechanical engineering, energy, instrument making, telecommunications, etc. in the West. An activity thereof in the field of innovation is especially indicative. For example, in the United States, only small businesses provide almost half of all scientific and technological innovations. More than $80 \%$ of US exports of high-tech products are made in enterprises with fewer than 50 employees [13].

And in Russia, SMBs are represented mainly by trade and construction businesses, real estate companies and other insignificant firms for the country's economy. Of course, such a business, by definition, cannot play a decisive role in the economic life of Russia.

In addition to all, Russian business is in no way tune in to innovation. And in the conditions of tremendous technological shifts in the world, this is indispensable. Moreover, the situation in this area is far from favorable. Equipment wear is very high. Even in the oil industry, the rate of obsolete equipment is $50 \%$, and it is even higher in other industries. At the same time, the level of innovative activity in industry has been fluctuating for many years within only $10 \%$ [14].

In this regard, it is necessary to reorient the business to new tasks, and its activation in production activities, and an increase in its competitiveness, etc. The formation of a new type of entrepreneur capable of innovative activities is of particular importance. And for this, he must have, in addition to the usual qualities for an entrepreneur, also such as a tendency to scientific and technological innovations, risk, be susceptible to change, resistant to stress, etc.

The population of our country does not yet have a very high opinion of modern entrepreneurs. As shown by sociological studies conducted by the All-Russian Center for the Study of Public Opinion (VTsIOM), the majority of respondents believe that the origin of large capitals is probably of a dubious nature and is most likely associated even with criminal means such as bribery, fraud, speculation, resale, theft, robbery. And real entrepreneurial spirit in production activity, hard work, business qualities, professional talent are, in their opinion, a less common way of capital accumulation. The respondents 
also endow modern business with unsightly qualities, such as commercialism, a tendency to deceive, amateurism, promiscuity in the means of achieving goals, etc. [15].

Although, generally, the population does not oppose wealth. Moreover, according to surveys, every third citizen of the Russian Federation (32\%) would like to do business, and $15 \%$ are already doing it [16]. This means that large capital in our society is recognized only if it is honestly earned. This is the manifestation of the main aspects of the Russian mentality, built on the principles of social justice and equality.

Under these conditions, the disunity between the population and entrepreneurs can be overcome only if the so-called activity component prevails in the activities of the latter and they strive not only for their own enrichment, but also to strengthen the economic power of Russia.

\section{Conclusion}

Thus, entrepreneurship in our country has a rather long history. But it began to acquire its classical expression only as capitalist relations were established. According to generally accepted human characteristics, it was far from ideal, since it was primarily concerned with personal enrichment and subjected its workers to merciless forms of exploitation.

At the same time, entrepreneurs have made a great contribution to the economic development of Russia, skillfully combining personal interests with the tasks of society. Manufacturers and breeders proved to be capable of finding new economic solutions, while showing the representative examples of business ethics. They left a significant trace in the cultural life of Russia, actively participating in charity and patronage. It would be advisable for modern entrepreneurs to adopt all these positive qualities. But perhaps the greatest advantage of entrepreneurs of the past was that they were characterized by the so-called activity component, which is still lacking for most representatives of modern business, but what determines their status, as well as the loyalty of public opinion.

In addition, modern entrepreneurship must take into account new trends in the Russian economy and in the world as a whole. One cannot but reckon with the fact that there has been a reorientation from gigantomania, to which the business aspired in the past, to small and medium-sized businesses. Special attention should also be paid to innovative activities, which will allow for the technological modernization of production and, accordingly, increase its efficiency.

\section{References}

1. The history of entrepreneurship in Russia in 2 books (1999-2000)

2. S. Vorobiev. Small business in Russia in the context of economic reforms at the turn of 1980-1990 (2008)

3. A. Logunov, Russian entrepreneurship in 1991-2003: social image and culture of business relations, (2007)

4. O.A. Nikiforov, Legal support of entrepreneurship in Siberia. Kemerovo (2000)

5. D Birch. Digital Identify Management: Technological, Business and Social Implication (2017)

6. W. Yartner . Entrepreneurship as Organizing: Selected Papers of William B. Yartner. Edward Elgar Publishing (2016)

7. Shane Scott. A General Theory of Entre - preneurship: The Individual - opportunity Nexus. Cheltenham (2003)

8. N. Aldrich. Entrepreneurial Strategies in New Organizational Populations (2000) 
9. W. Baumol. The Microtheory of Innovative Entrepreneurship. Princeton University Press (2010)

10. Russian entrepreneurship of the XIX - early XX century, rusempire.ru

11. A.N. Pershikov. History of Russian entrepreneurship. Tomsk (1999)

12. E. Chervyakov, A. Malikov, Small business in Russia, tadviser.ru

13. Innovation policy. Russia and the world (2012)

14. Kuznetsov, Economy and Life, 28 (2019)

15. A.S. Ruchka, The phenomenon of entrepreneurship in modern Russia, cyberleninka.ru

16. M. Bimatov, Modern entrepreneur, 1(2009) 